\title{
Evaluating Mustard Seed Meal for Weed Suppression in Potato (Solanum tuberosum)
}

\author{
Rick A. Boydston ${ }^{1}$, Steven F. Vaughn ${ }^{2}$, Charles L. Webber III $^{3}$ \& Bernardo Chaves-Cordoba ${ }^{4}$ \\ ${ }^{1}$ USDA, Agriculture Research Service, Grain Legume Genetics and Physiology Research Unit, Prosser, WA, \\ USA \\ ${ }^{2}$ USDA, Agriculture Research Service, Functional Foods Research Unit, Peoria, IL, USA \\ ${ }^{3}$ USDA, Agriculture Research Service, Sugarcane Research Unit, Houma, LA USA \\ ${ }^{4}$ Washington State University, Prosser, WA, USA \\ Correspondence: Rick A. Boydston, USDA, Agriculture Research Service, Grain Legume Genetics and \\ Physiology Research Unit, 24106 N Bunn Road, Prosser, WA 99350, USA. Tel: 1-509-786-9267. E-mail: \\ rick.boydston@ars.usda.gov
}

Received: November 21, 2017

Accepted: December 20, 2017

Online Published: January 15, 2018

doi:10.5539/jas.v10n2p48

URL: https://doi.org/10.5539/jas.v10n2p48

\begin{abstract}
Mustard seed meal (MSM) derived from Sinapis alba controls weeds for several weeks following application to soil, but also has potential to injure the planted crop. Producers of certified organic potatoes typically utilize a combination of cover crops, soil hilling, harrowing, and cultivation for weed control. Once the potato canopy nears row closure, most late emerging weeds are suppressed by the dense potato canopy. MSM may have value for early season weed suppression in potato, but has not been previously tested. Our objectives were to determine the weed control efficacy and potato tolerance to MSM. We evaluated response of potatoes and weeds to MSM applied at 1.1, 2.2, and 4.5 $\mathrm{MT} \mathrm{ha}^{-1}$ applied in a band on the potato hill just after a shallow harrowing and prior to potato emergence as part of an integrated weed management program in potatoes. MSM applied at 2.2 and 4.5 MT ha ${ }^{-1}$ reduced early season grass and broadleaf weed density 73 to $99 \%$ and 54 to $98 \%$, respectively, in potato and reduced late season broadleaf weed biomass 71 to $94 \%$ in all three years tested. Early season grass weed density in potato was reduced by MSM at 2.2 and $4.5 \mathrm{MT} \mathrm{ha}^{-1}$. Late season grass weed biomass was reduced by the highest rate of $4.5 \mathrm{MT} \mathrm{ha}^{-1}$. MSM at $4.5 \mathrm{MT} \mathrm{ha}^{-1}$ caused minor injury to potato ( 3 to $15 \%$ ) at 3 weeks after emergence, but did not reduce total tuber yields or percentage of US No.1 tubers. MSM could be a component of an integrated weed control program in potato.
\end{abstract}

Keywords: agricultural by-products, allelopathy, integrated weed management, natural products, organic weed control

\section{Introduction}

Consumer demand for certified organic produce grown without synthetic pesticides continues to increase and with the proliferation of organic agriculture, the need for new bioherbicides to control weeds has grown (Cai \& $\mathrm{Gu}, 2016)$. Weed management in conventional potato production relies heavily on synthetic herbicides due to their outstanding efficacy, ease of use, and relatively low cost. More U.S. potato hectares (75\%) are treated with the herbicide metribuzin than any other pesticide and $91 \%$ of potato hectares receive an herbicide (Guenthner, Wiese, Pavlista, Sieczka, \& Wyman, 1999; USDA-NASS, 2014). Weed management in organically grown potatoes typically consists of a combination of an early cultivation that removes the top of the hill formed at planting (drag off), a cultivation to reform the hill (rehilling) that uproots and buries early emerging weed seedlings prior to potato emergence, additional shallow cultivations if needed, and reservoir tillage (dammer-diking) that creates shallow pockets in the furrows to improve water infiltration and prevent runoff (Boydston \& Vaughn, 2002; Boydston, 2010). Once the potato canopy is near row closure, later emerging weeds are largely suppressed by the dense potato canopy. Excessive cultivation decreases soil organic matter, increases soil erosion, and has potential to injure crop roots. A biopesticide that could control weeds and decrease the need for cultivation would be useful. 
White mustard produces oil that is used for biodiesel production and culinary uses and mustard seed meal (MSM) is a co-product of the commercial oil pressing process (Brown, 2006). The use of products derived from natural sources to control pests is appealing, and developing new uses for MSM may increase the profitability of biodiesel production (Brown, 2006; Cai \& Gu, 2016). MSM contains glucosinolates that typically undergo enzymatic hydrolysis to isothiocyanates, SCN2, nitriles, and other compounds when added to moist soil (Brown, Morra, McCaffrey, Auld, \& Williams, 1991; Borek \& Morra, 2005; Vaughn \& Berhow, 2005). The predominant glucosinolate in $S$. alba seed is 4-hyroxybenzyl glucosinolate or sinalbin, which ultimately yields SCN2, a compound partly responsible for herbicidal activity of MSM (Daxenbichler, Spencer, Carlson, Rose, Brinker, \& Powell, 1991; Borek \& Morra, 2005; Hansson, Morra, Borek, Snyder, Johnson-Maynard, \& Thill, 2008). MSM applied at rates ranging from 113 to $450 \mathrm{~g} \mathrm{~m}^{-2}$ to the soil surface of container-grown ornamentals reduced annual bluegrass (Poa annua L.), common chickweed [Stellaria media (L.) Vill.], and creeping woodsorrel (Oxalis corniculata L.) emergence over an 8-wk period without injury to the established ornamental plants (Boydston, Vaughn, \& Anderson, 2008a). MSM applied at $2 \mathrm{MT}^{\mathrm{ha}}{ }^{-1}$ reduced emergence and biomass of wild oat (Avena fatua), Italian ryegrass (Lolium multiflorum), redroot pigweed (Amaranthus retroflexus), and prickly lettuce (Lactuca serriola) (Handiseni, Brown, Zemetra, \& Mazzola, 2011). MSM at $1 \mathrm{MT}^{\mathrm{ha}^{-1}}$ was less effective on reducing weed emergence and biomass than $2 \mathrm{MT} \mathrm{ha}^{-1}$ and two broadleaf weed species were suppressed greater than two grass weed species (Handiseni et al., 2011). MSM applied at rates from 2.2 to $6.7 \mathrm{MT} \mathrm{ha}^{-1}$ suppressed emergence of annual weeds greater than or equal to corn gluten meal applied at equivalent rates in greenhouse trials (Yu \& Morishita, 2014).

Although MSM suppresses weed emergence and growth, it also can negatively affect crop seed germination and growth (Rice, Johnson-Maynard, Thill, \& Morra, 2007; Earlywine, Smeda, Teuton, Sams, \& Xiong, 2010; Boydston, Morra, Borek, Clayton, \& Vaughn, 2011). MSM derived from Sinapis alba applied to the soil at 2.2 and $4.5 \mathrm{MT} \mathrm{ha}^{-1}$ reduced weed emergence by 76 to $91 \%$ for a period of $4 \mathrm{wks}$ in onion (Allium cepa) (Boydston et al., 2011). However, onions were severely injured when MSM was applied at the 1-leaf stage or earlier. Beets (Beta vulgaris) and lettuce (Lactuca sativa) were injured when seeding into MSM amended soil (Rice et al., 2007). Wheat emergence was inhibited by seed meals from 15 glucosinolate-containing plant species when applied at $1 \%(\mathrm{w} / \mathrm{w})$ to a sandy loam soil (Vaughn, Palmquist, Duval, \& Berhow, 2006). Delaying planting of the crop following MSM application may reduce phytotoxicity of MSM to the crop, but would also limit the longevity of weed suppression in the crop. Transplanted broccoli and direct seeded spinach were tolerant of MSM incorporated into the soil at 1.2 and 4.5 $\mathrm{MT} \mathrm{ha}^{-1}$ two weeks prior to planting (Shrestha, Rodriguez, Pasakdee, \& Bañuelos, 2015).

Corn gluten meal is one of many products extracted from corn during the wet milling process and has been demonstrated to have herbicidal activity when applied preemergence to weeds (Christians, 1993; Yu \& Morishita, 2014). Dried distillers grains with solubles (DDG) are a less expensive byproduct of ethanol production commonly fed to cattle and reduced emergence of common chickweed and annual bluegrass when applied to the surface of potting soil at relatively high rates of 8 to $16 \mathrm{MT} \mathrm{ha}^{-1}$ ) (Boydston, Vaughn, \& Collins, 2008b). The relatively high rate of DDG required for herbicidal activity may make it less practical as a bioherbicide, but its nitrogen content ( $4.4 \%$ by wt.) makes it appealing as an organic fertilizer.

To be useful for weed control in potato production systems, rates and timing of applications of MSM must be determined in order to minimize the potential for phytotoxicity to the crop. Potato is a relatively deep-planted crop that is grown from a vegetative tuber which may allow it to escape injury typically observed when MSM is applied preemergence to crops grown from a true seed. Potatoes generally take 3 to 5 weeks to emerge depending on planting depth, soil temperatures, and seed condition. This allows for early cultivation and rehilling operations that control early weed flushes (Boydston \& Vaughn, 2002; Boydston, 2010). A harrow or rod weeder operation that removes the top of the potato hill and leaves a flat topped hill (termed "drag off") is often practiced when potato shoots have sprouted, but still not emerged. Applying MSM following drag off may provide several weeks of weed control without damage to potato and possibly eliminate the need for additional cultivation, which can bring new weed seed near the soil surface where it can subsequently germinate (Grundy, Mead, \& Burston, 1999). Once emerged, most potato cultivars grow rapidly and provide a dense canopy that is closed within 7 to 8 weeks, shading out later emerging weeds (Connell, Binning, \& Schmitt, 1999).

This research evaluated the response of potato and weeds to three rates of MSM applied to the soil surface after harrowing off the tops of potato hills prior to potato emergence. A single rate of DDG was included as a comparison treatment representing an organic amendment containing a similar amount of nitrogen, but with nominal herbicidal activity at the rate used. 


\section{Materials and Methods}

\subsection{Site Conditions and Management}

All studies were conducted at the USDA-ARS Paterson research farm from 2006 to 2008 near Paterson, WA. The soil was a Quincy sand (mixed mesic Xeric Torripsamments) containing $0.4 \%$ organic matter and $\mathrm{pH}$ 7.0. Wheat preceeded potatoes each year and straw was removed. Fields were chisel plowed, disked, and harrowed in the spring to prepare ground for potato planting. Preplant fertilizer was applied based on soil tests and in-season nitrogen was applied through a center pivot irrigation system and based on leaf petiole sampling (Lang, Stevens, Thornton, Pan, \& Victory, 1999). Potato, var. 'Umatilla Russet' was planted in 2006 and var. 'Ranger Russet' in 2007 and 2008 at a seed piece spacing of $22 \mathrm{~cm}$ in rows spaced $86 \mathrm{~cm}$ apart. Seed pieces were placed $17 \mathrm{~cm}$ deep with a 6-row potato planter. Three to four weeks after planting (Table 1), the top of potato hills that were formed during planting were harrowed with a shallow operated rod weeder to control early germinating weeds and to form a flat-topped hill which provided a level surface for the mustard seed meal application. Plots were irrigated using center pivot irrigation and standard fungicides and insecticides were applied as needed to control pests other than weeds according to standard potato pest management practices in the western United States (Strand, 2006).

DDG was obtained from a commercial ethanol plant near West Burlington, IA (Big River Resources, LLC). MSM from S. alba cultivar 'IdaGold' was obtained locally (McKay Seed Co., Moses Lake, WA). Mustard seed was cold pressed and extruded flakes were run through a hammer mill to obtain a more uniform and spreadable granular material. Glucosinolate content of MSM was determined in 2006 and 2008 by a modification of a high performance liquid chromatography (HPLC) method developed by Betz and Fox (1994) and described previously (Boydston et al., 2011). Sinalbin quantitation was determined from a standard curve prepared from purified sinalbin previously isolated from defatted white mustard seed meal using the method of Vaughn and Berhow (2005). Three subsamples were tested from each batch of MSM and the entire process repeated once.

MSM was applied at 1.1,2.2, and 4.5 MT ha ${ }^{-1}$ and DDG at 2.2 MT ha ${ }^{-1}$ concentrated in a $31 \mathrm{~cm}$ wide band on the top of each potato hill shortly after harrowing (Table 1). Plots were sprinkler irrigated with $0.6 \mathrm{~cm}$ water within $4 \mathrm{~h}$ of application. A nontreated control treatment was included. In 2008, an additional treatment consisting of an application of rimsulfuron applied postemergence at $26 \mathrm{~g} \mathrm{ha}^{-1}$ on May 13, 2008 and then hand weeded at weekly intervals to remove any weeds that escaped herbicide treatment. Treatments were arranged in a randomized complete block design replicated four times. Individual plots were 1.7 by $6.1 \mathrm{~m}$ and contained two potato rows.

All plots were reservoir tilled (dammer-diked) in early- to mid-May each year which controlled most early emerging weeds in the furrows and sides of the potato hill (Table 1).

Table 1. Timing of potato planting, harrowing of hill tops, mustard seed meal application, reservoir tillage, and harvest operations in 2006, 2007, and 2008 at Paterson, WA

\begin{tabular}{llllll}
\hline Year & Potatoes Planted & Hills Harrowed & Mustard Seed Meal Applied & Reservoir Tilled & Potatoes Harvested \\
\hline 2006 & March 31 & April 24 & April 25 & May 18 & August 29 \\
2007 & March 19 & April 11 & April 11 & May 1 & September 6 \\
2008 & March 19 & April 21 & April 28 & May 9 & September 9 \\
\hline
\end{tabular}

\subsection{Data Collection}

Weed density by species was recorded on May 16, 2006; May 9, 2007; and May 12, 2008 by counting all weeds within four, $0.25 \mathrm{~m}^{2}(30$ by $83 \mathrm{~cm}$ ) rectangular quadrats randomly placed and centered on the top of the potato hills (within the MSM treated area) in each plot. Weed density and biomass by species were collected August 21, 2006 and 2007, and August 26, 2008 from four, randomly placed, $0.25 \mathrm{~m}^{2}$ quadrats in each plot. All grass and all broadleaf species were grouped separately for weed density and weed biomass data analysis. Weed biomass (dry weight) was determined by clipping plants at the soil surface, drying at $40^{\circ} \mathrm{C}$ for $48 \mathrm{~h}$ and weighing.

Potato injury was rated visually on a scale of $0=$ no injury to $100=$ death at 12,20 to 27 , and 31 to 40 days after emergence (DAE). Potato yield was determined by weighing tubers mechanically harvested from the entire plot. Tubers were graded by size and quality according to USDA grading standards (Anonymous, 1991). U.S. No. 1 potatoes were grouped into five size categories; 113 to $170 \mathrm{~g}, 171$ to $227 \mathrm{~g}, 228$ to $284 \mathrm{~g}, 285$ to $340 \mathrm{~g}$, and $>340$ 
$\mathrm{g}$ and the percentage by weight in each category determined. Although not considered U.S. No. 1, undersized tubers $(<113 \mathrm{~g})$ that contained no blemishes or malformations were also included in size grading. Specific gravity was measured on ten, 230 - to 280 -g tubers in each treatment.

\subsection{Data Analysis}

Analysis of variance (ANOVA) was performed using the PROC GLIMMIX procedure in SAS (Statistical Analysis Systems ${ }^{\circledR}, 2014$, version 9.4, SAS Institute Inc., SAS Campus Drive, Cary, NC 27513, USA). Blocks and years by blocks were treated as random factors. Data were pooled across years when no significant year by treatment interaction was detected. Data from each year were analyzed and presented separately when a significant year by treatment interaction was detected or when the elimination of treatments with no variance from the analysis (crop injury data) resulted in a different number of treatments among years. Mean separation was conducted using Tukey-Kramer for the calculated LSMEANS ( $\mathrm{P}=0.05)$. When crop injury data contained only one treatment mean greater than zero, $t$ tests at 0.05 level were used to compare means to zero.

\section{Results}

MSM tested in 2006 and 2008 contained $23.82 \pm 0.09 \mathrm{mg} \mathrm{g}^{-1}$ dry wt and $36.99 \pm 2.12 \mathrm{mg} \mathrm{g}^{-1}$ dry wt sinalbin, respectively. MSM was not analyzed for sinalbin content in 2007.

\subsection{Weed Density and Biomass}

In 2006 , hairy nightshade accounted for $47 \%$ of total early season weed counts, followed by barnyardgrass and large crabgrass, redroot pigweed, and common lambsquarters. Hairy nightshade was the most prevalent broadleaf weed in 2007 accounting for 39\% of the total weed early season weed counts, followed by barnyardgrass and large crabgrass, and lesser amounts of Russian thistle, common lambsquarters, and redroot pigweed. In 2008, no grass weeds were emerging on May 12 and hairy nightshade comprised $98 \%$ of the emerged weeds with sparse amounts of Russian thistle and common lambsquarters.

There were significant treatment effects and year by treatment effects on early season weed density so the data are presented by year. Early season grass weed density was reduced by the two highest rates of MSM and broadleaf weed densities were reduced by the highest rate of MSM compared to nontreated checks in 2006 (Table 2). DDG at 2.2 $\mathrm{MT} \mathrm{ha}^{-1}$ and the 1.1 MT ha-1 rate of MSM did not reduce weed densities. In 2007, early season grass and broadleaf weed densities were reduced by the two highest rates of MSM compared to the nontreated checks. In 2007, the lowest rate of MSM and DDG at $2.2 \mathrm{MT}^{-1}$ also reduced broadleaf weed density compared to the nontreated checks, but did not reduce grass weed density (Table 2). There were no early season grass weeds in 2008, but broadleaf weed density was significantly reduced by all MSM rates tested. DDG at 2.2 $\mathrm{MT} \mathrm{ha}^{-1}$ did not reduce early season broadleaf weed density in 2008. Total (grass and broadleaf) early season weed density in nontreated checks was greatest in 2007 averaging 141 seedlings per $\mathrm{m}^{2}$. 
Table 2. Early season grass and broadleaf weed density in potatoes following preemergence treatment of mustard seed meal or dried distillers grains in 2006, 2007, and 2008 near Paterson, WA

\begin{tabular}{|c|c|c|c|c|}
\hline \multirow{2}{*}{ Year } & \multirow{2}{*}{ Treatment } & \multirow{2}{*}{ Rate } & \multicolumn{2}{|c|}{ Early season weed density } \\
\hline & & & Grass & Broadleaf \\
\hline \multirow{7}{*}{2006} & & ---- MT ha' ${ }^{-1}$---- & -------- no. m² ------- & ------- no. $\mathrm{m}^{2}$------- \\
\hline & Nontreated control & - & $15 \mathrm{~b}$ & $24 \mathrm{ab}$ \\
\hline & Dried distillers grains & 2.2 & $24 \mathrm{a}$ & $31 \mathrm{a}$ \\
\hline & Mustard seed meal & 1.1 & $9 \mathrm{bc}$ & $29 \mathrm{a}$ \\
\hline & Mustard seed meal & 2.2 & $4 \mathrm{c}$ & $11 \mathrm{bc}$ \\
\hline & Mustard seed meal & 4.5 & $2 \mathrm{c}$ & $3 c$ \\
\hline & $\operatorname{Pr}>F$ & & $<0.0001$ & 0.0003 \\
\hline \multirow[t]{6}{*}{2007} & Nontreated control & - & $80 \mathrm{a}$ & $61 \mathrm{a}$ \\
\hline & Dried distillers grains & 2.2 & $33 \mathrm{ab}$ & $38 \mathrm{~b}$ \\
\hline & Mustard seed meal & 1.1 & $24 \mathrm{ab}$ & $18 \mathrm{bc}$ \\
\hline & Mustard seed meal & 2.2 & $10 \mathrm{~b}$ & $10 \mathrm{c}$ \\
\hline & Mustard seed meal & 4.5 & $1 \mathrm{~b}$ & $3 \mathrm{c}$ \\
\hline & $\operatorname{Pr}>F$ & & 0.019 & $<0.0001$ \\
\hline \multirow[t]{10}{*}{2008} & Nontreated control & - & 0 & $53 \mathrm{a}$ \\
\hline & Dried distillers grains & 2.2 & 0 & $34 \mathrm{ab}$ \\
\hline & Mustard seed meal & 1.1 & 0 & $12 \mathrm{bc}$ \\
\hline & Mustard seed meal & 2.2 & 0 & $4 \mathrm{c}$ \\
\hline & Mustard seed meal & 4.5 & 0 & $1 \mathrm{c}$ \\
\hline & Herbicide control & & 0 & $43 \mathrm{a}$ \\
\hline & $\operatorname{Pr}>\mathrm{F}$ & & - & $<0.0001$ \\
\hline & Combined AOV & Year & $<.0043$ & 0.286 \\
\hline & & Treatment & 0.0006 & $<.0001$ \\
\hline & & Yr*Trt & 0.0018 & 0.0004 \\
\hline
\end{tabular}

Note. ${ }^{a}$ Lsmeans within a column and year followed by the same letter do not differ significantly at $\mathrm{P}=0.05$ according to Tukey-Kramer lsmeans test.

These results are in agreement with previous research where MSM at 2.2 to 4.5 MT ha ${ }^{-1}$ reduced early season weed density in field trials on onions, cucurbits, broccoli, and spinach (Boydston et al., 2011; Shrestha et al., 2015; Webber, White, Boydston, \& Shrefler, 2017). The relatively poor weed suppression with DDG at 2.2 MT $\mathrm{ha}^{-1}$ is in agreement with greenhouse studies by Boydston et al. (2008b) in which rates of $400 \mathrm{~g} \mathrm{~m}^{-2}$ (equivalent to $4 \mathrm{MT} \mathrm{ha}^{-1}$ ) or lower applied to the soil surface did not suppress weeds.

There were both year and treatment effects on late season weed density and biomass, but not significant year by treatment interactions, so the combined data are presented (Table 3). Late season grass weed density was not impacted by MSM or DDG treatment, but grass weed biomass was reduced from $154 \mathrm{~g} \mathrm{~m}^{-2}$ in nontreated checks to $33 \mathrm{~g} \mathrm{~m}^{-2}$ by the $4.5 \mathrm{MT} \mathrm{ha}^{-1}$ rate of MSM. Both late season broadleaf weed density and biomass were reduced by the highest rate of MSM compared to the nontreated check. Broadleaf weed biomass was reduced from $644 \mathrm{~g}$ $\mathrm{m}^{-2}$ in nontreated checks to $40 \mathrm{~g} \mathrm{~m}^{-2}$ by MSM applied at 4.5 MT ha ${ }^{-1}$ (Table 3). The 1.1 and 2.2 $\mathrm{MT} \mathrm{ha}^{-1} \mathrm{rates}$ of MSM reduced late season broadleaf weed biomass compared to nontreated checks, but did not significantly reduce grass weed biomass. DDG did not significantly reduce late season grass or broadleaf weed counts or biomass. Handiseni et al. (2011), and Wang, Gu, Niu, and Baumann (2015) reported greater suppression of broadleaf weed species than grass weed species with MSM from $S$. alba. In those studies, MSM derived from Brassica juncea was more effective on grass species than S. alba MSM. Late season weed biomass, consisting mainly of barnyardgrass, was not reduced in broccoli and spinach treated with up to $4.5 \mathrm{MT} \mathrm{ha}^{-1} \mathrm{MSM}$, indicating that the weed suppressive effects of MSM did not last season-long (Shrestha et al., 2015).

Field tests of MSM in several vegetable crops have resulted in lower early season weed density, but often failed to control later emerging weeds (Boydston et al., 2011; Shrestha et al., 2015; Webber et al., 2017). In the current study, we suspect the vigorous growing potato canopy likely prevented later emerging weeds from establishing or producing considerable biomass. When higher rates of MSM within the crop row was combined with 
reservoir tillage in the interrow, early season weeds were often suppressed and the potato canopy was able to provide good weed suppression for the remainder of the season.

Table 3. Late season grass and broadleaf weed density and biomass in potatoes following preemergence treatment of mustard seed meal or dried distillers grains in 2006, 2007, and 2008 near Paterson, WA

\begin{tabular}{|c|c|c|c|c|c|}
\hline \multirow{2}{*}{ Treatment } & \multirow{2}{*}{ Rate } & \multicolumn{2}{|c|}{ Late season weed density } & \multicolumn{2}{|c|}{ Late season weed biomass } \\
\hline & & Grass & Broadleaf & Grass & Broadleaf \\
\hline & ---- MT ha ${ }^{-1}$---- & ---- no. $\mathrm{m}^{-2}$---- & --- no. $m^{-2}---$ & ---- $\mathrm{g} \mathrm{m}^{-2}----$ & ---- $\mathrm{g} \mathrm{m}^{-2}$---- \\
\hline Nontreated control & - & 36 & $20 \mathrm{a}$ & $154 \mathrm{a}$ & $644 \mathrm{a}$ \\
\hline Dried distillers grains & 2.2 & 22 & $22 \mathrm{a}$ & $94 \mathrm{ab}$ & $373 \mathrm{ab}$ \\
\hline Mustard seed meal & 1.1 & 52 & $20 \mathrm{a}$ & $131 \mathrm{ab}$ & $306 \mathrm{bc}$ \\
\hline Mustard seed meal & 2.2 & 33 & $10 \mathrm{ab}$ & $63 \mathrm{ab}$ & $185 \mathrm{bc}$ \\
\hline Mustard seed meal & 4.5 & 21 & $3 \mathrm{~b}$ & $33 \mathrm{~b}$ & $40 \mathrm{c}$ \\
\hline \multicolumn{6}{|l|}{ Year } \\
\hline 2006 & & $15 \mathrm{~b}$ & $24 \mathrm{a}$ & 125 & $515 \mathrm{a}$ \\
\hline 2007 & & $10 \mathrm{~b}$ & $6 \mathrm{~b}$ & 85 & $295 \mathrm{ab}$ \\
\hline 2008 & & $72 \mathrm{a}$ & $16 \mathrm{ab}$ & 74 & $119 \mathrm{~b}$ \\
\hline \multirow[t]{3}{*}{ Combined AOV } & Year & 0.011 & 0.0398 & 0.3419 & 0.0213 \\
\hline & Treatment & 0.1344 & 0.0001 & 0.0236 & $<0.0001$ \\
\hline & Yr*Trt & 0.723 & 0.1879 & 0.287 & 0.0602 \\
\hline
\end{tabular}

Note. ${ }^{\text {a }}$ Lsmeans within a column and treatment or year followed by the same letter do not differ significantly at $\mathrm{P}=0.05$ according to Tukey-Kramer lsmeans test. Lsmeans not followed by a letter indicate there was no significant treatment or year effect.

\subsection{Potato Response and Yield}

Twelve days after potato emergence (DAE), slight injury was observed in all three years ranging from 4 to $6 \%$ for the 4.5 MT ha ${ }^{-1}$ rate of MSM (Table 4). In 2008, the $2.2 \mathrm{MT} \mathrm{ha}^{-1}$ rate of MSM also caused 2\% injury at 12 DAE, but was not statistically different from nontreated controls. Injury consisted of chlorotic and stunted growth of the emerged potato shoots. The greatest potato injury of $15 \%$ was observed in 2008 at 22 DAE with the high rate of MSM. In 2008, MSM was applied only two days before potato emergence which may have increased the potential for MSM to injure potato shoots close to the surface. Potato injury was never extensive and declined after 3 to 4 weeks after emergence.

There was no significant year or year by treatment interaction on total potato tuber yield, so the combined data is presented (Table 4). Potatoes treated with MSM at 2.2 $\mathrm{MT} \mathrm{ha}^{-1}$ yielded 70.5 MT ha-1, significantly greater than nontreated checks and DDG treated potatoes, which averaged 60.2 and 59.0 MT ha ${ }^{-1}$, respectively (Table 4). The lack of early season in-row weed control in the nontreated checks and DDG treatments likely contributed to the lower tuber yields. Potatoes treated with MSM at 1.1 and 4.5 MT ha yielded 63.6 and 65.2 MT ha ${ }^{-1}$, respectively.

In 2006 , the percentage of tubers in the US No.1 category averaged $82 \%$ and was not impacted by soil amendments tested (Table 4). In 2007, MSM at 1.1 MT ha ${ }^{-1}$ averaged the greatest percentage of US No.1 tubers ( $93 \%$ by weight) and the nontreated checks and MSM at $4.5 \mathrm{MT} \mathrm{ha}^{-1}$ averaged the least ( 86 and $88 \%$ by weight, respectively) (Table 4). However, in 2008, MSM at 4.5 MT ha ${ }^{-1}$ averaged the greatest percentage of US No.1 tubers ( $94 \%$ by weight) and nontreated checks averaged the least ( $89 \%$ by weight) (Table 4$)$. The individual positive effects of reduced early season weed competition and potential negative effects of potato phytotoxicity from MSM treatments on both total tuber yield and percentage of US No. 1 tubers cannot be completely sorted out in the current study. In 2008, a weed-free herbicide control treatment was included that yielded equal to the nontreated control indicating that uncontrolled in-row weeds in 2008 were not great enough to negatively impact potato tuber yield and percent US No. 1 tubers.

In 2006 and 2008 there were no significant differences in percentages of tubers in various size classes among treatments (data not shown). In 2006, the greatest percentage of tubers were in the 113 to $170 \mathrm{~g}$ ( $29 \%$ by weight) and 170 to $227 \mathrm{~g}$ ( $23 \%$ by weight) size categories and least percentage in the $>340 \mathrm{~g}$ size category ( $6 \%$ by weight) (data not shown). In 2008, the greatest percentage of tubers were in the $>340 \mathrm{~g}$ size category, averaging $33 \%$ by weight and the least percentage of tubers were in the $<113 \mathrm{~g}$ size category, averaging $5 \%$ by weight 
(data not shown). The later harvest date in 2008 compared to 2006 probably contributed to the larger percentage of tubers in the larger size categories.

Table 4. Early season potato injury, total potato tuber yield, and percentage of U.S. No.1 tubers following preemergence treatment of mustard seed meal or dried distillers grains in 2006, 2007, and 2008 near Paterson, WA

\begin{tabular}{|c|c|c|c|c|c|c|c|}
\hline Year & Treatment & Rate & Injury $12 \mathrm{DAE}$ & $\begin{array}{l}\text { Injury20 to } 27 \\
\text { DAE }\end{array}$ & $\begin{array}{l}\text { Injury31 to } 40 \\
\text { DAE }\end{array}$ & Total tuber yield & $\begin{array}{l}\text { Percent } \\
\text { U.S. No. } 1\end{array}$ \\
\hline & & MT ha $^{-1}$ & $\%$ & $\%$ & $\%$ & MT ha $^{-1}$ & $\%$ of total \\
\hline \multirow[t]{6}{*}{2006} & Nontreated control & - & 0 & 6.3 & 3.8 & - & 82.7 \\
\hline & Dried distillers grains & 2.2 & 0 & 1.3 & 0 & - & 78.9 \\
\hline & Mustard seed meal & 1.1 & 0 & 1.3 & 1.3 & - & 80.1 \\
\hline & Mustard seed meal & 2.2 & 0 & 2.5 & 0 & - & 82.4 \\
\hline & Mustard seed meal & 4.5 & 4.5 & 0 & 0 & - & 84.1 \\
\hline & $\operatorname{Pr}>F$ or $P>|t|$ & & 0.0729 & 0.1696 & 0.1393 & & 0.287 \\
\hline \multirow[t]{6}{*}{2007} & Nontreated control & - & 0 & $0 \mathrm{~b}$ & 0 & - & $85.8 \mathrm{c}$ \\
\hline & Dried distillers grains & 2.2 & 0 & $0 \mathrm{~b}$ & 0 & - & $89.1 \mathrm{bc}$ \\
\hline & Mustard seed meal & 1.1 & 0 & $0 \mathrm{~b}$ & 0 & - & $93.2 \mathrm{a}$ \\
\hline & Mustard seed meal & 2.2 & 0 & $0 \mathrm{~b}$ & 0 & - & $92.5 \mathrm{ab}$ \\
\hline & Mustard seed meal & 4.5 & 3.8 & $10 \mathrm{a}$ & 1.8 & - & $88.3 \mathrm{c}$ \\
\hline & $\operatorname{Pr}>F$ or $P>|t|$ & & 0.0577 & $<0.0295$ & 0.0689 & & 0.0001 \\
\hline \multirow[t]{7}{*}{2008} & Nontreated control & - & $0 \mathrm{~b}$ & $0 \mathrm{~b}$ & $0 \mathrm{~b}$ & - & $88.9 \mathrm{~b}$ \\
\hline & Dried distillers grains & 2.2 & $0 \mathrm{~b}$ & $0 \mathrm{~b}$ & $0 \mathrm{~b}$ & - & $91.6 \mathrm{ab}$ \\
\hline & Mustard seed meal & 1.1 & $0 \mathrm{~b}$ & $0 \mathrm{~b}$ & $0 \mathrm{~b}$ & - & $91.3 \mathrm{ab}$ \\
\hline & Mustard seed meal & 2.2 & $2 b$ & $1.3 \mathrm{~b}$ & $0 \mathrm{~b}$ & - & $91.9 \mathrm{ab}$ \\
\hline & Mustard seed meal & 4.5 & $6 \mathrm{a}$ & $15 \mathrm{a}$ & $9 \mathrm{a}$ & - & $93.5 \mathrm{a}$ \\
\hline & Herbicide control & & $0 \mathrm{~b}$ & $0 \mathrm{~b}$ & $0 \mathrm{~b}$ & - & $91.4 \mathrm{ab}$ \\
\hline & $\operatorname{Pr}>F$ or $P>|t|$ & & 0.0409 & $<0.0150$ & $<0.0029$ & & 0.0735 \\
\hline \multirow[t]{8}{*}{ All Years } & Nontreated control & - & - & - & - & $60.2 \mathrm{~b}$ & - \\
\hline & Dried distillers grains & 2.2 & - & - & - & $59.0 \mathrm{~b}$ & - \\
\hline & Mustard seed meal & 1.1 & - & - & - & $63.6 \mathrm{ab}$ & - \\
\hline & Mustard seed meal & 2.2 & - & - & - & $70.5 \mathrm{a}$ & - \\
\hline & Mustard seed meal & 4.5 & - & - & - & $65.2 \mathrm{ab}$ & - \\
\hline & Combined AOV & Year & 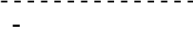 & - & - & 0.3513 & $<0.0001$ \\
\hline & & Treatment & - & - & - & 0.0097 & 0.0144 \\
\hline & & Yr*Trt & - & - & - & 0.3481 & 0.005 \\
\hline
\end{tabular}

Note. ${ }^{\text {a }}$ Lsmeans within a column and year followed by the same letter do not differ significantly at $\mathrm{P}=0.05$ according to Tukey-Kramer lsmeans test or according to t test at $\mathrm{P}=0.05$ (cases with only one mean greater than zero). Means not followed by a letter indicate there was no significant treatment effect.

In 2007, there was a significant treatment effect on the percentage of tubers in various size classes (Figure 1). MSM at $2.2 \mathrm{MT} \mathrm{ha}^{-1}$ resulted in a greater percentage of tubers in the 228 to $284 \mathrm{~g}$ and 285 to $340 \mathrm{~g}$ size classes and fewer undersized tubers $(<113 \mathrm{~g})$ and small tubers 113 to $170 \mathrm{~g}$ size class compared to nontreated checks, which averaged a greater percentage of undersized and small tubers and lesser percentage in the 228 to $284 \mathrm{~g}$ and 285 to $340 \mathrm{~g}$ size categories. Similarly, MSM at $1.1 \mathrm{MT} \mathrm{ha}^{-1}$ also resulted in a greater number of tubers in the 228 to $284 \mathrm{~g}$ size class and fewer in the undersized class $(<113 \mathrm{~g})$ than the nontreated checks. Weed competition in the nontreated checks likely contributed to the greater percentage of smaller-sized tubers (Boydston \& Vaughn, 2002). Weed pressure (both early season weed density and late season weed biomass) tended to be greater in 2007 than in 2006 and 2008 and is likely the reason a significant response in tuber size was observed in 2007. However, MSM at 4.5 MT ha ${ }^{-1}$ generally reduced early and late season weeds the most but resulted in tuber size profile similar to nontreated checks (Figure 1). Perhaps the early season phytotoxicity from the high rate of MSM in 2007 contributed to a slightly smaller tuber size profile compared to the $2.2 \mathrm{MT} \mathrm{ha}^{-1}$ rate of MSM.

Potato tuber specific gravity was significantly affected by year $(\mathrm{P}<0.0001)$ and there was a significant year by treatment effect $(\mathrm{P}=0.0197)$. MSM or DDG had no effect on tuber specific gravity in 2006 and 2007. In 2008, 
MSM at 2.2 and 4.4 $\mathrm{MT} \mathrm{ha}^{-1}$ averaged greater tuber specific gravity (1.0824 and 1.0820, respectively) than potatoes treated with DDG or herbicide, which averaged 1.0776 and 1.0785, respectively (data not shown).

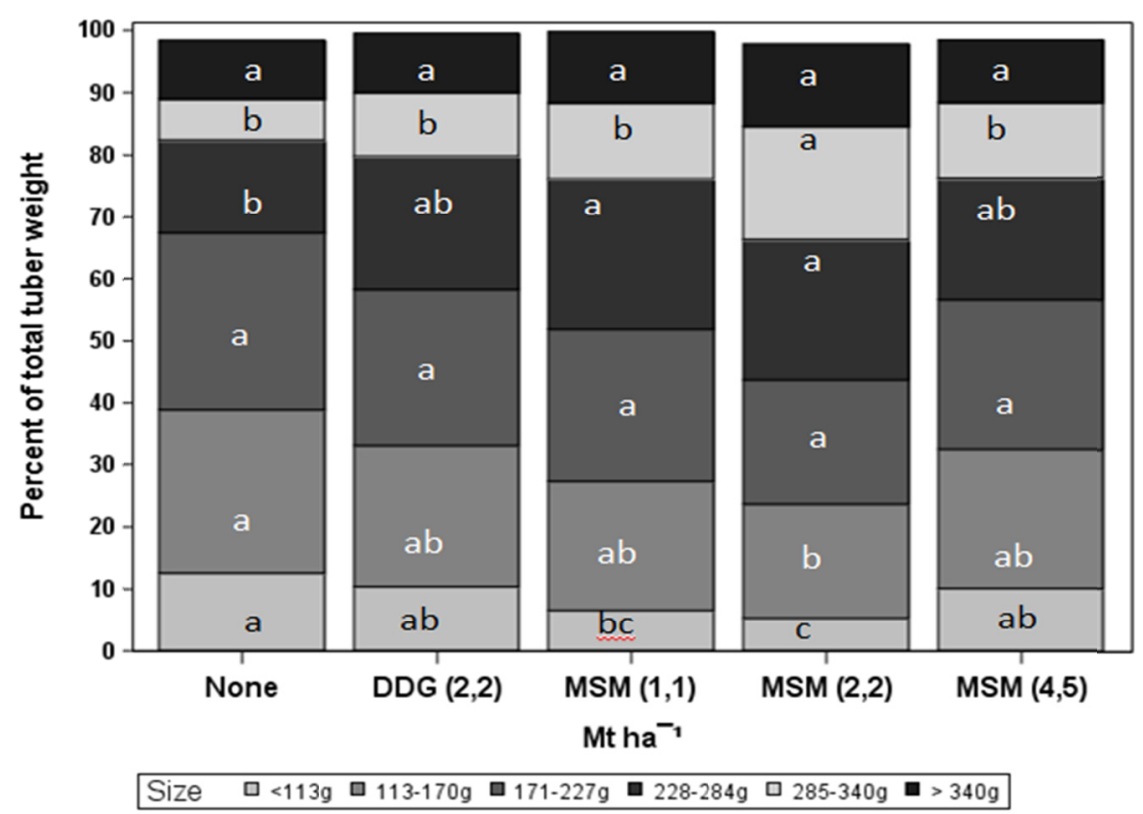

Figure 1. Size distribution of U.S. No. 1 potato tubers and undersized tubers $(<113 \mathrm{~g})$ with no blemishes in 2007 following preemergence treatment of mustard seed meal (MSM) or dried distillers grains (DDG) in near Paterson, WA. Columns do not total to $100 \%$ as U.S. No. 2 tubers were not included. Lsmeans within a tuber size category containing the same letter do not differ significantly at $\mathrm{P}=0.05$ according to Tukey-Kramer lsmeans test

\section{Discussion}

Unlike previous reports of MSM causing excessive crop injury (Earlywine et al., 2010; Boydston et al., 2011; Webber et al., 2017), potatoes were able to escape significant injury from MSM applied to the soil surface. Potatoes are planted much deeper and plantlets establish from a large vegetative seed piece possibly protecting the crop from significant injury. The positional selectivity of MSM observed on small-seeded shallow weeds compared to deeper-planted potatoes could allow for growers to successfully utilize MSM for early season weed suppression in the potatoes. Surface applied MSM may also have utility for in-season weed control in other deep-planted crops, such as sweet potatoes, and in established perennial or annual crops without causing appreciable crop injury.

MSM may have particular utility for weed suppression in organic production where effective herbicides are lacking. MSM is an allowed input in certified organic production providing the oil extraction process is a natural process, such as pressing, that does not add solvents or other synthetic compounds to the meal. In addition, MSM contains 7\% nitrogen and could act as an additional nitrogen source, which is often limited in organic systems (Shrestha et al., 2015).

The herbicidal activity of MSM has been known for over 10 years, but MSM has had limited adoption in production agriculture, primarily due to limited local availability, potential for crop injury, and the difficulty of hauling and evenly spreading the large the quantities required for weed control. Mustard is not widely produced in most regions of the United States, whereas Canada produces about 200,000 MT on approximately 200,000 ha (Anonymous, 2017). India, Pakistan, Nepal, and Europe are also major mustard producers. The large quantities of MSM required for weed suppression necessitates a localized supply to reduce hauling and spreading costs. Banded applications of granular materials like MSM on a larger scale require specialized application equipment. Such equipment has been previously demonstrated using corn gluten meal and could be custom built (Webber $\&$ Shrefler, 2007). Overcoming supply limitations and increasing the availability of spreading equipment will be required in most regions before there is wide use of MSM in production agriculture. Since the herbicidal activity of MSM is generally nonselective (injures most weeds and many crops) use patterns that demonstrate crop safety 
in regards to placement, rate, crop growth stage, and transplants versus direct seeded are crucial for greater adoption by producers.

MSM applied at 2.2 and 4.5 $\mathrm{MT} \mathrm{ha}^{-1}$ just after a shallow harrowing and prior to potato emergence suppressed early season weed emergence and coupled with the shading of later emerging weeds by the crop canopy, prevented potato tuber yield loss from excessive weed competition. MSM could be a component of an integrated weed control program in potato if limitations of availability and spreading are overcome.

\section{Acknowledgements}

The authors thank AgriNorthwest for supplying land, irrigation water, and power to the research site near Paterson, WA. We also thank Marcus Seymour, Dallas Spellman, Encarnacion Rivera, and Treva Anderson for their excellent technical support.

\section{References}

Anonymous. (1991). United States Standards for Grades of Potatoes (p. 10). Beltsville, MD: USDA Agricultural Marketing Service.

Anonymous. (2017). Statistics Canada. Field and Special Crops (Production). Retrieved November 13, 2017, from http://www.statcan.gc.ca/tables-tableaux/sum-som/101/cst01/prim11b-eng.htm

Betz, J. M., \& Fox, W. D. (1994). High-performance liquid chromatographic determination of glucosinolates in Brassica vegetables. Food phytochemicals I: Fruits and vegetables (pp. 181-196). ACS Symposium Series, American Chemical Society, Washington, DC.

Borek, V., \& Morra, M. J. (2005). Ionic thiocyanate (SCN2) production from 4-hydroxybenzyl glucosinolate contained in Sinapis alba seed meal. Journal of Agriculture and Food Chemistry, 47, 3837-3842. https://doi.org/10.1021/jf051570r

Boydston, R. (2010). Managing weeds in potato rotations without herbicides. American Journal of Potato Research, 87, 420-427. https://doi.org/10.1007/s12230-010-9153-4

Boydston, R. A., \& Vaughn, S. F. (2002). Alternative Weed Management Systems Control Weeds in Potato (Solanum tuberosum). Weed Technology, 16, 23-28. https://doi.org/10.1614/0890-037X(2002)016[0023: AWMSCW]2.0.CO;2

Boydston, R. A., Morra, M., Borek, V., Clayton, L., \& Vaughn, S. F. (2011). Onion and weed response to mustard (Sinapis alba) seed meal. Weed Science, 59, 546-552. https://doi.org/10.1614/WS-D-10-00185.1

Boydston, R. A., Vaughn, S. F., \& Anderson, T. (2008a). Mustard (Sinapis alba) seed meal suppresses weeds in container-grown ornamentals. HortScience, 43, 800-803.

Boydston, R. A., Vaughn, S. F., \& Collins, H. P. (2008b). Response of weeds and ornamental plants to potting soil amended with dried distillers grains. HortScience, 43, 191-195.

Brown, J. (2006). Oil Crop Potential for Biodiesel Production: Summary of Three Years of Spring Mustard Research: Methodologies, Results, and Recommendations. National Renewable Energy Laboratory (SR-510-36309). Retrieved November 13, 2017, from http://www.nrel.gov/docs/fy05osti/36309.pdf

Brown, P. C., Morra, M. J., McCaffrey, J. P., Auld, D. L., \& Williams, L. III. (1991). Allelochemicals produced during glucosinolate degradation in soil. Journal of Chemical Ecology, 17, 2021-2034. https://doi.org/ 10.1007/BF00992585

Cai, X., \& Gu, M. (2016). Bioherbicides in organic horticulture. Horticulturae, 2(2), 3. https://doi.org/10.3390/ horticulturae 2020003

Christians, N. E. (1993). The use of corn gluten meal as a natural preemergence weed control in turf. International Turfgrass Society Research Journal, 7, 284-290.

Connell, T. R., Binning, L. K., \& Schmitt, W. G. (1999). A Canopy Development Model for Potatoes. American Journal of Potato Research, 76, 153-159. https://doi.org/10.1007/BF02853580

Daxenbichler, M. E., Spencer, G. F., Carlson, D. G., Rose, G. B., Brinker, A. M., \& Powell, R. G. (1991). Glucosinolate composition of seeds from 297 species of wild plants. Phytochemistry, 30, 2623-2638. https://doi.org/10.1016/0031-9422(91)85112-D

Earlywine, D. T., Smeda, R. J., Teuton, T. C., Sams, C. E., \& Xiong, X. (2010). Evaluation of oriental mustard (Brassica juncea L. Czern.) seed meal for weed suppression in turf. Weed Technology, 24, 440-445. https://doi.org/10.1614/WT-D-09-00058.1 
Grundy, A. C., Mead, A., \& Burston, S. (1999). Modelling the effect of cultivation on seed movement with application to the prediction of weed seedling emergence. Journal of Applied Ecology, 36, 663-678. https://doi.org/10.1046/j.1365-2664.1999.00438.x

Guenthner, J. F., Wiese, M. V., Pavlista, S. D., Sieczka, J. B., \& Wyman, J. (1999). Assessment of pesticide use in the U.S. potato industry. American Journal of Potato Research, 76, 25-29. https://doi.org/10.1007/ BF02853554

Handiseni, M., Brown, J., Zemetra, R., \& Mazzola, M. (2011). Herbicidal Activity of Brassicaceae Seed Meal on Wild Oat (Avena fatua), Italian Ryegrass (Lolium multiflorum), Redroot Pigweed (Amaranthus retroflexus), and Prickly Lettuce (Lactuca serriola). Weed Technology, 25, 127-134. https://doi.org/10.1614/WT-D-1000068.1

Hansson, D., Morra, M. J., Borek, V., Snyder, A. J., Johnson-Maynard, J. L., \& Thill, D. C. (2008). Ionic thiocyanate (SCN2) production, fate, and phytotoxicity in soil amended with Brassicaceae seed meals. Journal of Agriculture and Food Chemistry, 56, 3912-3917. https://doi.org/10.1021/jf800104x

Lang, N. S., Stevens, R. G., Thornton, R. E., Pan, W. L., \& Victory, S. (1999). Potato Nutrient Management for Central Washington. Washington State University Cooperative Extension Bulletin (EB1871, p. 18).

Rice, A. R., Johnson-Maynard, J. L., Thill, D. C., \& Morra, M. J. (2007). Vegetable crop emergence and weed control following amendment with different Brassicaceae seed meals. Renewable Agriculture and Food Systems, 22, 204-212. https://doi.org/10.1017/S1742170507001743

Shrestha, A., Rodriguez, A., Pasakdee, S., \& Bañuelos, G. (2015). Comparative efficacy of white mustard (Sinapis alba L.) and soybean (Glycine max L. Merr.) seed meals as bioherbicides in organic broccoli (Brassica oleracea Var. Botrytis) and spinach (Spinacea oleracea) production. Communication in Soil Science and Plant Analysis, 46, 33-46. https://doi.org/10.1080/00103624.2014.956884

Strand, L. (2006). Integrated Pest Management for Potatoes in the Western United States (2nd ed., p. 167) University of California Statewide Integrated Pest Management Program. Oakland, CA: Agriculture and Natural Resources Communication Services, University of California.

USDA-NASS. (2015). 2014 Agricultural chemical use survey: Fall potatoes. NASS Highlights. Retrieved November 13, 2017, from https:/www.nass.usda.gov/Surveys/Guide_to_NASS_Surveys/Chemical_Use/ 2014_Potato_Highlights/ChemUseHighlights_FallPotatoes_2014.pdf

Vaughn, S. F, Palmquist, D. E., Duval, S. M., \& Berhow, M. A. (2006). Herbicidal activity of glucosinolate-containing seedmeals. Weed Science, 54, 743-748. https://doi.org/10.1614/WS-06-007R.1

Vaughn, S. F., \& Berhow, M. A. (2005). Glucosinolate hydrolysis products from various plant sources: $\mathrm{pH}$ effects, isolation and purification. Industrial Crops Production, 21, 193-202. https://oi.org/10.1016/ j.indcrop.2004.03.004

Wang, X., Gu, M., Niu, G., \& Baumann, P. A. (2015). Herbicidal activity of mustard seed meal (Sinapis alba 'IdaGold' and Brassica juncea 'Pacific Gold') on weed emergence. Industrial Crops and Products, 77, 1004-1013. https://doi.org/10.1016/j.indcrop.2015.09.070

Webber, C. L. III, \& Shrefler, J. W. (2007). Corn Gluten Meal Applicator for Weed Control in Organic Vegetable Production. Journal of Vegetable Science, 12, 19-26. https://doi.org/10.1300/J484v12n04_03

Webber, C. L. III, White, P. M. Jr., Boydston, R. A., \& Shrefler, J. W. (2017). Impact of Mustard Seed Meal Application s on Direct-Seeded Cucurbits and Weed Control. Journal of Agriculture Science, 9(8), 81-90. https://doi.org/10.5539/jas.v9n8p81

Yu, J., \& Morishita, D. W. (2014). Response of seven weed species to corn gluten meal and white mustard (Sinapis alba) seed meal rates. Weed Technology, 28, 259-265. https://doi.org/10.1614/WT-D-13-00116.1

\section{Copyrights}

Copyright for this article is retained by the author(s), with first publication rights granted to the journal.

This is an open-access article distributed under the terms and conditions of the Creative Commons Attribution license (http://creativecommons.org/licenses/by/4.0/). 